\title{
Electricity Generation and Its Impact on Real GDP and Real Exports of Pakistan: A Co-integration Analysis
}

\author{
Furrukh Bashir * $\quad$ Ismat Nasim $^{\dagger} \quad$ Ammar Ismail ${ }^{\ddagger}$
}

\begin{abstract}
The objective of the study is to present the influence of Electricity Generation on Real GDP and Real Exports of Pakistan using time series data from 1972 to 2014. The results of Johansen Co-integration test revealed that Electricity Generation, Employed Labour Force, Gross Fixed Capital Formation and Terms of Trade have a positive influence on while Exchange Rate is having negative relationship with Real GDP. In other model, Electricity Generation, Employed Labor Force, Gross Fixed Capital Formation, Relative Prices are evidence of increasing real Exports. On the other side, Exchange Rate is negatively associated with real Exports of Pakistan.
\end{abstract}

Keywords: Electricity generation, exchange rate, terms of trade, real GDP, real exports, relative price, Solow growth model.

\section{Introduction}

Electricity plays an important role in the economy, especially in developing economies like Pakistan because the efficient usage of various resources depends directly on the electricity. Almost all sectors, whether it is agriculture sector, industrial sector, or household, all depend directly on the electricity.

This research is made keeping in view the current and the prolonged economic situation of Pakistan. Pakistan is confronting grave problems of energy crisis as well as negative net exports. Pakistan's imports are more than she exports, causing a considerable trade deficit and creating the shortage of foreign exchange reserves. On the other hand, she is also facing several problems like Industrial shut down, declining production, increasing unemployment, underutilization of resources, inflation and falling investment. The exports and electricity generation are very nearly linked to each other because when the electricity generation will increase than the industries that have been closed, will restart and start producing which may contribute to an increment in the end product that will be applied to meet domestic needs and the surplus will be available to export. When exports increase it will gain a portion of foreign exchange for Pakistan making balance of payment favorable. On the other side, there will be an increase in work opportunities and therefore the purchasing power of masses will increase that will raise aggregate demand and thus results in higher real GDP.

\footnotetext{
${ }^{*}$ Lecturer, Department of Economics at The Islamia University of Bahawalpur, Pakistan. (Bahawalnagar Campus), E-mail: farrukh.bashir@iub.edu.pk

${ }^{\dagger}$ Ph. D Scholar of Economics at Bahauddin Zakariya University, Multan, Pakistan.

${ }^{\ddagger}$ Research Scholar of Economics at The Islamia University of Bahawalpur, Pakistan. (Bahawalnagar Campus)
} 
The overall situation of real exports, real GDP and Electricity production is shown in Figures 1, 2 and 3. Real Exports and real GDP are continually increasing as there is a rise in electricity production. This proves that real exports and real GDP are highly associated with electricity production.

Figure 1: Real Export

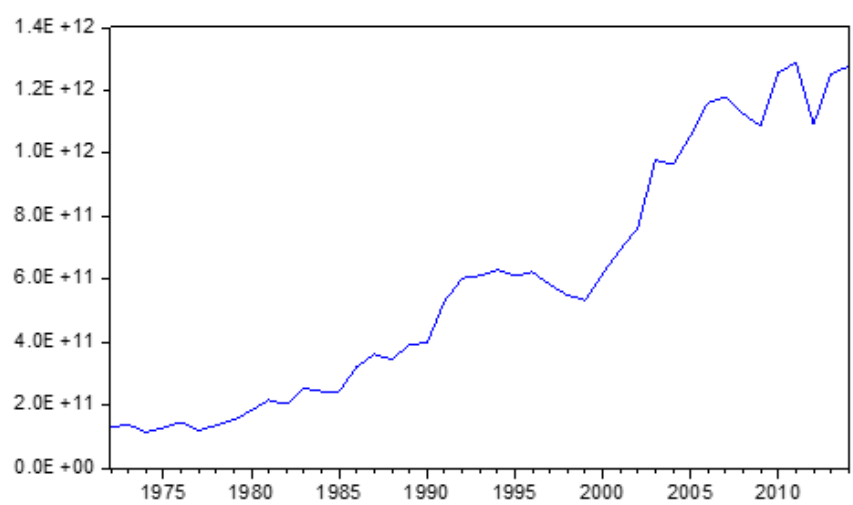

Figure 2: Real GDP

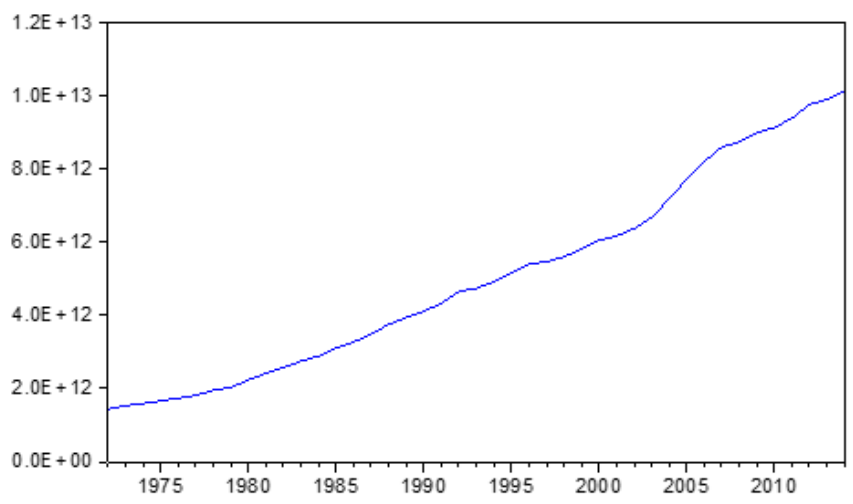

The rationale of this research is to suggest some policies to reduce trade deficits and to raise real GDP of Pakistan. Because Pakistan's economy is severely facing the problem of the trade deficit and low real growth rates, which is causing a depreciation of currency. The objective of the study is to present the influence of Electricity Generation on Real GDP and Exports of Pakistan. This research is divided into five sections that are the introduction, literature review, data and methodology, results and discussions and conclusion of the overall study in sections $1,2,3,4$ and 5 respectively. 
Figure 3: Electricity Production

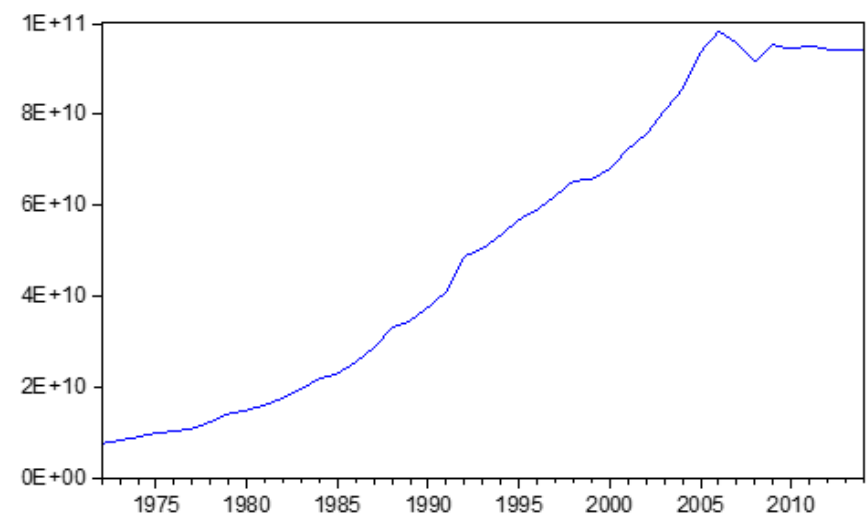

\section{Literature Review}

There have been published a lot of literature on the issues of Real GDP and Real Exports in Pakistan and at international level. Few studies are considered here to overview the past studies divided into two sub-sections. One is from Pakistan's economy and other from International economies regarding the same issue.

\section{Reviews from International Economies}

Lackó (1999) made an analysis to disclose that in post-socialist countries, the variation in the electricity intensities was not found to reflect necessarily the growth of hidden elements of the economy. Data used by the researcher was time series for the period ranging from 1989 to 1994 . The variables used in the research were Maximal Rate of Unemployment, The Change of the Official Output, The Change of the Share of Industry in the Production of GDP, and the Change in the Electricity Consumption. The results showed that the growth of the hidden elements of the economy was not founded to be effected necessarily by the variation of electricity intensities in post-socialist countries. In eighteen post-socialist countries, the results based on econometric and statistical analysis disclosed that to explain differences in the variations of electricity intensity, the registered structural and measured changes were found to be sufficient.

The researcher, Asafu-Adjaye (2000) by taking the variables, Price, Energy Consumption and Income made an attempt for Thailand, Indonesia, India and Philippines to explore the causal relationships between income and energy consumption. This paper used the annual time series data covering the period ranging from 1973 to 1995 . The research by applying Granger Causality test traced out that in Indonesia and India, unidirectional granger causality ran from energy to income. While in the case of Philippines and Thailand, bidirectional Granger causality ran from energy to income. In Indonesia and India, in the long run, there was unidirectional Granger causality running from prices and energy 
to income. The income, energy and prices, in the case of the Philippines and Thailand, were mutually causal. In the causal chain, it was found that price effects were relatively less significant. The view that income and energy were neutral with respect to each other was not found to be supported by the results concluded in this research except the case of India and Indonesia were in the short run, neutrality was observed.

Chontanawat, Hunt, and Pierse (2006) attempted to test the causality between the variables GDP and energy by using the annual time series data ranging from 1960 to 2000 for 30 OECD and data ranging from 1971 to 2000 for most of 78 non-OECD countries on the variables Real GDP and Final Electricity Consumption. Causality from GDP to Energy Consumption was more prevalent in the case of OECD countries. Causality form energy to GDP resulted in OCED countries. It was found that the degree of causality of energy to GDP was less in the developing countries as compared to the developed countries.

An attempt to inspect the causal relationship was made by Aktaş and Yilmaz (2012) for Turkey using the annual time series data ranging from 1970 to 2004. After applying the Granger Causality test, a bidirectional causal relationship was found to exist. Unidirectional causality was found running from the GNP to Electricity Consumption in the long run.

Dhungel (2008) conducted the study to determine the causal relationship between oil and total commercial energy, Per Capita Consumption of Coal, Per Capita Real Gross Domestic Product and Electricity using the annual time series data from 1980 to 2004. Unidirectional causality was found running from Per Capital Real Gross Domestic Product to Per Capita Electricity Consumption; from commercial energy consumption, oil and coal to Per Capital Real Gross Domestic Product.

Noor and Siddiqi (2010) attempted to inspect the causal link between economic growth and energy use for five South Asian countries. The researchers used the annual time series data from 1971 to 2006. The coefficient of Electricity Consumption Per Capita for India, Nepal and Bangladesh was found to be positive which meant that an increase in the energy consumption would lead to an increase in the GDP Per Capita. While in the case of the other two countries, Sri-Lanka and Pakistan, the coefficient of the energy consumption was found to be negative, which meant that an increase in the energy consumption would reduce GDP Per Capita. Similarly the unidirectional causality was found to exist from Labor to Capital.

Shahbaz and Feridun (2012) analyzed empirically the co integration and causality between economic growth, capital and electricity consumption by using the annual time series data ranging from 1980 to 2011 in Romania. ARDL Co-integration test was applied, which resulted that capital, economic growth and electricity consumption were co-integration. The marginal effect of capital and electricity consumption on economic growth revealed that economic growth was positively affected by electricity consumption and was found to be statistically significant. Capital was also found to be a significant driver of economic growth and it was found to have a positive relationship with the economic growth. Bidirectional causality was also found between capital use and economic growth as well as between economic growth and electricity consumption. On the other hand a unidirectional causal relationship was discovered from capital use to electricity consumption.

Uslu and Polat (2011) conducted the research to determine the relationship between 
Employment, Electricity Consumption and Real Income by using the annual time series data ranging from 1923 to 2006 in case of Turkey. The results showed that Employment, Electricity Consumption and Real Income were co integrated in the long run. The causality was found from Real Income and Employment to Electricity Consumption. No existence of causality was found in the Employment and Real Income equations.

\section{Reviews from Pakistan Economy}

An attempt to trace out the causal relationships, in Pakistan, between economic growth and energy consumption was made by Aqeel and Butt (2001). Annual time series data on the variables Gross Domestic Product and Electricity Consumption covering the period 1955-1956 to 1995-1996 was used in this research work. The results of the study revealed that economic growth leads to the growth in petroleum consumption. As far as the gas sector was concerned, both the gas consumption and economic growth did not affect each other. On the other hand, however, in the power sector; electricity consumption was leading to economic growth.

Hye and Riaz (2008) determined the relationship between Energy Consumption and Economic Growth. They used annual time series data covering the period from 1971 to 2007. They observed that when they applied the ARDL, the Electricity Consumption being the dependent variable, the two variables Energy Consumption and Economic Growth had only one co-integrated relationship. On the other hand they applied the Granger causality to find out the direction of causality between the energy consumption and Economic Growth and explored that in the both short run and long run the changes in the Economic Growth caused changes in Energy Consumption. While on the other hand, in the short run, Energy Consumption caused Economic Growth but not in the long run. The declared a policy that Pakistan would have to invest in the energy sector especially in nuclear power, natural gas, hydroelectricity, coal and wind.

Shahbaz and Feridun (2012) made an attempt to find out equilibrium relationship between economic growth and electricity consumption. Annual time series data ranging from 1971 to 2008 was used. The study explored that Economic Growth and Electricity Consumption were found be in the equilibrium relationship and in the case of Pakistan economic growth would lead to electricity consumption but not the vice versa. The research concluded that economic growth caused electricity consumption but not vice versa in Pakistan. As far as the policy is concerned, they suggested that such as electricity consumption conservation, the government would have to be adopted such policies that are environmental friendly. The utilization and exploration of energy sources such as wind power, solar and hydro that are environmental friendly could maintain balance between environment and economic growth.

Masuduzzaman (2012) explored the co integration between GDP, Electricity Consumption and Investment. In his research annual time series data ranging from 1981 to 2011 were used. There was a unidirectional relationship running from electricity consumption to economic growth. Moreover the results of causality test explored that investment caused economic growth and electricity caused investment but not the vice versa. The short run elasticity of economic growth with respect to investment and electricity consumption were 
shorter than their long run elasticity.

A research was conducted by Ahmad, Hayat, Hamad, and Luqman (2012) to determine the relationship between economic growth and energy consumption in Pakistan. Positive relationship between Gross Domestic Product and Energy Consumption was found.

For Pakistan, Atif and Siddiqi (2010) made an attempt to determine the causal relationship between GDP and electricity consumption. The study used the annual time series data ranging from 1971 to 2007. Unidirectional Granger Causality was found running from Electricity Consumption to Economic Growth.

Javid, Javid, and Awan (2013) determined the existence of long run relationship between the variables Electricity Consumption and Real GDP Per Capita in case of Pakistan. In the study, the researchers used the annual time series data ranging from 1971 to 2008. The researchers found the existence the unidirectional causality running from Electricity Consumption to Real GDP Per Capita as well as the existence of a long run relationship between Electricity Consumption and Real GDP Per Capital was also found. Raza, Shahbaz, and Nguyen (2015) also confirmed the bidirectional causal relationship between energy consumption and gross domestic product.

\section{Data and Methodology}

\section{Data Sources, Type and Range}

The study employs annual time series data from 1972 to 2014. Log-Log forms of the models are used to estimate the results. The data for all the variables are obtained from World Development Indicators published by the World Bank and Economic Survey of Pakistan (2014-15) published by the Federal Bureau of Statistics of Pakistan.

\section{Methodological Discussions}

Most of the macroeconomic models may have problem of spurious regression because most macroeconomic variables are trended. So to solve it, we may take the difference in the series successively until the stationary is achieved. Once the stationary is achieved, we can take this stationary series for regression analysis. But this is not an ideal solution because by applying the first difference it may loss the long run properties and the models formulated by taking the differences is not an ultimate solution. The basic idea is that if there are economic time series that are integrated of the same order (they are non stationary), which we know are related (mainly through a theoretical framework), then trying to check whether we can find a way to combine them together into a single series which is itself non stationary. If this is possible, then the series that exhibits this property is called co-integrated. To estimate the results, the following tests would be applied in the sequence as given.

1. Augmented Dickey Fuller test for examining Stationarity of variables

2. Lag Length Selection using Akaike, Schwarz or Hannan - Quinn Information Criterion 


\section{Johansen Co-integration test for Long run estimates}

4. Error Correction Model for Short run estimates

\section{Augmented Dickey Fuller test (ADF)}

At the formal level, Stationarity can be checked by finding out if the time series data contain a unit root or not. Augmented Dickey Fuller (ADF) tests can be used for this purpose.

$$
\Delta Y_{t}=\beta_{1}+\beta_{2} t+\delta Y_{t-1}+\alpha_{i} \Delta Y_{t-i}+\epsilon_{t}
$$

Here $\mathrm{i}=1,2,3, \ldots \Delta Y_{t-i}$ it shows the i-time lagged value of dependent variable $Y_{t} . \epsilon_{t}$ is an error term (Raza, Shahbaz, \& Paramati, 2016; Raza, 2015).

\section{Lag Length Selection (Information Criteria)}

In order to select a model, the information criteria are used. A model contains The Kullback-Leibler quantity of information which is the distance from the true model and is measured by the log likelihood function. The notion of an information criterion is to provide a measure of information that strikes a balance between this measure of goodness of fit and the parsimonious specification of the model. The various information criteria differ in how to strike this balance.

The basic information criteria are given by;

Akaike Information criterion $(\mathrm{AIC})=-2(\mathrm{l} / \mathrm{T})+2(\mathrm{k} / \mathrm{T})$

Schwarz Information Criterion $(\mathrm{SC})=-2(\mathrm{l} / \mathrm{T})+\mathrm{k} \log (\mathrm{T}) / \mathrm{T}$

Hannan - Quinn Information Criterion $(\mathrm{HQ})=-2(\mathrm{l} / \mathrm{T})+2 \mathrm{k} \log (\log (\mathrm{T})) / \mathrm{T}$

\section{Johansen Co-integration Test}

The new technique for co-integration for long run as well as short run associations for multivariate equation is given by Johansen (1988). In order to present this approach; it is useful to expand the single equation error correction model to a multivariate. Let's assume that we have three variables, $Y_{t}, X_{t}$ and $W_{t}$ which can all be endogenous, i.e. we have that (using matrix notation for $\mathrm{Zt}=\left[T_{t}, X_{t}, W_{t}\right]$ ).

$$
Z_{t}=A_{1} Z_{t-1}+A_{2} Z_{t-2}+\ldots \ldots \ldots+A_{k} Z_{t-k}+\mu_{t}
$$

Vector error correction model (VECM) can be reformulated is as follows; 


$$
\Delta Z_{t}=r_{1} \Delta Z_{t-1}+r_{2} \Delta Z_{t-2}+\ldots \ldots \ldots . .+r_{k-1} \Delta Z_{t-k}+\Pi Z_{t-1}+\mu_{t}
$$

Where $r_{i}=\left(\mathrm{I}-A_{1}-A_{2}-\ldots \ldots . A_{k}\right)(\mathrm{I}=1,2, \ldots . ., \mathrm{k}-1) \& \Pi=-\left(\mathrm{I}-A_{1}-A_{2}-\ldots \ldots-A_{k}\right)$.

Here we need to carefully examine the $3 \times 3 \Pi$ matrix (The $\Pi$ matrix is $3 \times 3$ due to the fact that we assume three variables in $\left.Z_{t}=\left[T_{t}, X_{t}, W_{t}\right]\right)$. The $\Pi$ matrix contains information regarding the long run relationship. In fact ? = where will include the speed of adjustment to equilibrium coefficients while will be the long run matrix of coefficients.

Therefore the $\beta Z_{t-1}$ term is equivalent to the error correction term $\left(Y_{t-1}-\beta_{0}-\beta_{1}\right.$ $\left.X_{t}-1\right)$ in the single equation case, except that now $Z_{t}-1$ contains up to $(\mathrm{n}-1)$ vectors in a multivariate framework.

For simplicity, we assume that $\mathrm{k}=1$, so that we have only two lagged terms and the model is then the following:

$$
\left[\begin{array}{c}
\Delta Y_{t} \\
\Delta X_{t} \\
\Delta W_{t}
\end{array}\right]=r_{1}\left[\begin{array}{c}
\Delta Y_{t-1} \\
\Delta X_{t-1} \\
\Delta W_{t-1}
\end{array}\right]+\Pi\left[\begin{array}{c}
Y_{t-1} \\
X_{t-1} \\
W_{t-1}
\end{array}\right]+\epsilon_{t}
$$

Or

$$
\left[\begin{array}{c}
\Delta Y_{t} \\
\Delta X_{t} \\
\Delta W_{t}
\end{array}\right]=r_{1}\left[\begin{array}{c}
\Delta Y_{t-1} \\
\Delta X_{t-1} \\
\Delta W_{t-1}
\end{array}\right]+\left[\begin{array}{ll}
a_{11} & a_{12} \\
a_{21} & a_{22} \\
a_{31} & a_{32}
\end{array}\right]\left[\begin{array}{lll}
b_{11} & b_{21} & b_{31} \\
b_{12} & b_{22} & b_{32}
\end{array}\right]\left[\begin{array}{c}
Y_{t-1} \\
X_{t-1} \\
W_{t-1}
\end{array}\right]+\epsilon_{t}
$$

Let us now analyze only the error correction part of the first equation (i.e. for $\Delta Y_{t}$ on the left hand side) which gives;

$$
\Pi_{1} Z_{t-1}=\left[a_{11} \beta_{11}+a_{12} \beta_{12}\right]\left[a_{11} \beta_{21}+a_{12} \beta_{22}\right]\left[a_{11} \beta_{31}+a_{12} \beta_{32}\right]\left[\begin{array}{c}
Y_{t-1} \\
X_{t-1} \\
W_{t-1}
\end{array}\right]
$$

Where, $\Pi_{1}$ is the first row of the $\Pi$ matrix. The above equation can be rewritten as;

$$
\Pi_{1} Z_{t-1}=a_{11}\left(\beta_{11} Y_{t-1}+\beta_{21} X_{t-1}+\beta_{31} W_{t-1}\right)+a_{12}\left(\beta_{12} Y_{t-1}+\beta_{22} X_{t-1}+\beta_{32} W_{t-1}\right)
$$

Which shows clearly the co-integrating vectors with their respective speed of adjustment terms and $a_{11} \& a_{12}$.

Johansen (1988) proposed few steps for reliable results as discussed below.

- Johansen Co-integration Test is used for series that are integrated of the same order. So the first step is to run an Augmented Dicker Fuller (ADF) unit root test for all the variables in our model. If they are all stationary at first difference (they are all integrated of order one or I (1)) then we may proceed with Johansen Co-integration Test. 
- At the second step, lag length would be chosen using VAR models on the basis of minimum values of Final Predication Error (FPE), Akaike Information Criterion (AIC), and Hannan and Quinn information criterion (HQ). Using lag length and 10\% critical value choice for the J.C test. then

- Co-integration among variables may be examined by Eigen value or maximum likelihood method. Normalized coefficients are given under 1 co-integrating equation.

\section{Error Correction Model (ECM)}

Error Correction Model (ECM) approach is useful for estimating both short run and long run effects of one time series on another. Error Correction Models (ECMs) are category of multiple time series models that directly estimate the speed at which a dependent variable returns to equilibrium after a change in an independent variable (Alam, Raza, Shahbaz, \& Abbas, 2015). Economists are mainly interested in long-run relationship this constitutes a big problem, and in order to resolve this concept of co integration and the ECM are very useful.

\section{Model Specification}

The study focuses on the impact of Electricity Generation on the Real GDP and Real Exports of Pakistan and the study considers supply side of electricity. Considering Solow Growth Model, the given models incorporates Employed Labor Force (as a proxy of labor) and Gross Fixed Capital Formation (as a proxy of Capital stock) as main variables. Extended Solow models in general form are specified below;

$$
\begin{aligned}
& L R G D P_{t}=\alpha_{o}+\alpha_{1} L L A B F_{t}+\alpha_{2} L C A P_{t}+\alpha_{3} L E L P R_{t}+\alpha_{4} L E X R_{t}+\alpha_{5} L T O T_{t}+\mu_{i} \\
& L R E X P T_{t}=\beta_{o}+\beta_{1} L L A B F_{t}+\beta_{2} L C A P_{t}+\beta_{3} L E L P R_{t}+\beta_{4} L E X R_{t}+\beta_{5} L T O T_{t}+\beta_{6} L R P R_{t}+ \\
& \beta_{7} L R G D P_{t}+\lambda_{i}
\end{aligned}
$$

Gross fixed capital formation is already utilized as a proxy of Capital in their analysis by various economists like (Jawaid, 2014; Jawaid \& Raza, 2012).

Table 1

Definition of Variables

\begin{tabular}{llll}
\hline Variable & Definition & Expected Relationship & Unit of Measurement \\
\hline LRGDP & Real GDP & Dependent Variable/ Positive with Exports & Million Rupees \\
LREXPT & Real Exports & Dependent Variable & Million Rupees \\
LLABF & Employed labor Force & Positive & Millions \\
LCAP & Fixed Capital Formation & Positive & Million Rupees \\
LELPR & Electricity Production & Positive & GWH \\
LEXR & Exchange rate & Negative & Rupees per Dollar \\
LTOT & Terms of Trade & Positive & Ratio of Prices (PEXPORTS/PIMPORTS) \\
LRPR & Relative Prices & Positive & (PEXPORTS/GDPDEFLATOR) \\
\hline
\end{tabular}




\section{Results and Discussions}

\section{Augmented Dickey Fuller (ADF)}

The first step in Johansen Co-integration technique involves confirming the order of integration of all the variables used in the study. Table 2 presents the results of the ADF unit root test and reveals that all the variables are integrated at order one.

Table 2

ADF Unit Root Test

\begin{tabular}{|c|c|c|c|c|}
\hline VARIABLES & $\begin{array}{c}\text { TEST FOR UNIT } \\
\text { ROOT IN } \\
\end{array}$ & $\begin{array}{c}\text { INCLUDE IN } \\
\text { TEST EQUATION }\end{array}$ & PROBABILITY & RESULT \\
\hline LREXPT & $\begin{array}{l}\text { Level } \\
\text { 1st Difference }\end{array}$ & $\begin{array}{l}\text { Intercept } \\
\text { Intercept } \\
\text { Trend \& Intercept }\end{array}$ & $\begin{array}{l}0.800 \\
0.000 \\
0.000\end{array}$ & $\mathrm{I}(1)$ \\
\hline LRGDP & $\begin{array}{l}\text { Level } \\
\text { 1st Difference }\end{array}$ & $\begin{array}{l}\text { Intercept } \\
\text { Trend \& Intercept } \\
\text { Intercept } \\
\text { Trend \& Intercept }\end{array}$ & $\begin{array}{l}0.660 \\
0.230 \\
0.000 \\
0.000\end{array}$ & $\mathrm{I}(1)$ \\
\hline LRPR & $\begin{array}{l}\text { Level } \\
\text { 1st Difference }\end{array}$ & $\begin{array}{l}\text { Intercept } \\
\text { Trend \& Intercept } \\
\text { Intercept }\end{array}$ & $\begin{array}{l}0.380 \\
0.210 \\
0.000\end{array}$ & $\mathrm{I}(1)$ \\
\hline LEXR & $\begin{array}{l}\text { Level } \\
\text { 1st Difference }\end{array}$ & $\begin{array}{l}\text { Intercept } \\
\text { Trend \& Intercept } \\
\text { Intercept } \\
\text { Trend \& Intercept }\end{array}$ & $\begin{array}{l}0.970 \\
0.650 \\
0.000 \\
0.000\end{array}$ & $\mathrm{I}(1)$ \\
\hline LELPR & $\begin{array}{l}\text { Level } \\
\text { 1st Difference }\end{array}$ & $\begin{array}{l}\text { Intercept } \\
\text { Trend \& Intercept } \\
\text { Intercept } \\
\text { Trend \& Intercept }\end{array}$ & $\begin{array}{l}0.430 \\
0.120 \\
0.010 \\
0.000\end{array}$ & $\mathrm{I}(1)$ \\
\hline LCAP & $\begin{array}{l}\text { Level } \\
\text { 1st Difference }\end{array}$ & $\begin{array}{l}\text { Intercept } \\
\text { Trend \& Intercept } \\
\text { Intercept } \\
\text { Trend \& Intercept }\end{array}$ & $\begin{array}{l}0.190 \\
0.120 \\
0.000 \\
0.000\end{array}$ & $\mathrm{I}(1)$ \\
\hline LLABF & $\begin{array}{l}\text { Level } \\
\text { 1st Difference }\end{array}$ & $\begin{array}{l}\text { Intercept } \\
\text { Trend \& Intercept } \\
\text { Intercept } \\
\text { Trend \& Intercept }\end{array}$ & $\begin{array}{l}0.610 \\
0.270 \\
0.000 \\
0.000\end{array}$ & $\mathrm{I}(1)$ \\
\hline LTOT & $\begin{array}{l}\text { Level } \\
\text { 1st Difference }\end{array}$ & $\begin{array}{l}\text { Intercept } \\
\text { Trend \& Intercept } \\
\text { Intercept } \\
\text { Trend \& Intercept }\end{array}$ & $\begin{array}{l}0.930 \\
0.870 \\
0.000 \\
0.000\end{array}$ & $\mathrm{I}(1)$ \\
\hline
\end{tabular}

\section{Lag Length Selection Criteria}

The second step of Johansen Co-integration technique involves the selection of appropriate lag length using proper information criteria. We have used Schwarz information criterion (SC) and Hannan-Quinn information criterion (HQ) in our study and results is reported in the table 3. Favorable lag length that is selected in current analysis is assumed to be ' 1 ' in real GDP model and real exports model at which the values of information criteria are minimum. 
Table 3

\begin{tabular}{ccccc}
\multicolumn{2}{l}{ Lag Length Selection } \\
Lag & \multicolumn{2}{l}{ Real GDP Model } & \multicolumn{2}{l}{ Real Exports Model } \\
\cline { 2 - 5 } & SC & HQ & SC & HQ \\
\hline & & & & \\
$\mathbf{0}$ & -7.551649 & -7.7111 & -9.89439 & -10.08042 \\
$\mathbf{1}$ & $-20.19114^{*}$ & $-21.30730^{*}$ & $-21.60122^{*}$ & $-23.08943^{*}$ \\
$\mathbf{2}$ & -18.49154 & -20.5644 & -19.48237 & -22.27276 \\
\hline
\end{tabular}

\section{No. of Co-integrated Vectors}

In First model, the study has found a number of co-integrated equations using trace statistics and maximum Eigenvalue statistics. According to probabilities given in tables 4, the analysis rejects the null hypothesis that there is no co-integrated vector (None). Trace and Maximum Eigenvalue Statistics confirm the long run association among variables in both models of Real GDP and Real Exports.

Table 4

Unrestricted Cointegration Rank Test

\begin{tabular}{lcccc}
\hline $\begin{array}{l}\text { No. of Co-integ. } \\
\text { Equations }\end{array}$ & $\begin{array}{c}\text { Trace } \\
\text { Statistic }\end{array}$ & Prob. & $\begin{array}{c}\text { Max-Eigen } \\
\text { Statistic }\end{array}$ & Prob. \\
\hline \multicolumn{5}{c}{ Real GDP Model } \\
\hline None & 144.6297 & 0.0000 & 57.38437 & 0.0002 \\
At most 1 & 87.24533 & 0.0011 & 37.71232 & 0.0166 \\
At most 2 & 49.53300 & 0.0345 & 24.11166 & 0.1309 \\
At most 3 & 25.42135 & 0.1469 & 16.50247 & 0.1968 \\
At most 4 & 8.918871 & 0.3729 & 8.504046 & 0.3298 \\
At most 5 & 0.414825 & 0.5195 & 0.414825 & 0.5195 \\
\hline \multicolumn{5}{c}{} \\
\hline None & Real Exports Model & \\
At most 1 & 0.818208 & 217.6509 & 125.6154 & 0.0000 \\
At most 2 & 0.668569 & 147.7505 & 95.75366 & 0.0000 \\
At most 3 & 0.614869 & 102.4727 & 69.81889 & 0.0000 \\
At most 4 & 0.526826 & 63.35167 & 47.85613 & 0.0009 \\
At most 5 & 0.378452 & 32.67168 & 29.79707 & 0.0227 \\
At most 6 & 0.273961 & 13.17442 & 15.49471 & 0.1086 \\
\hline Source: Authors' Estimation & 0.001176 & 0.048224 & 3.841466 & 0.8262 \\
\hline
\end{tabular}

\section{Johansen Co-integration (Long run Estimates)}

The long run estimates of Real GDP and Real Export models are given in the table 5 respectively. The first column shows the name of the variables, second column describes the coefficients, third column states the standard errors, fourth column reveals the t-statistics and finally the fifth column contains the significant and insignificant relationships of all the variables.

The employed labor force has a positive relationship with real GDP and real exports. It may be justified increase in the labor force to our production process raises the total production of the country. Increasing production will lead to higher real GDP and real 
exports. These results are matched with (Uslu \& Polat, 2011). Gross Fixed Capital Formation (used as a proxy of Capital Stock) is revealed to be positive with real GDP and real Exports. Rising capital formation will be an indicative of increasing production of goods and services. It will ultimately lead to real GDP and real Exports of Pakistan. Statistically, the coefficient of capital in export model is insignificant.

Electricity Generation is found to have positive associations with real GDP and real exports. The reason is that producers will have an advantage of an excessive supply of power so they will establish more industries in order to earn profits. Establishment of new industries will increase production, real GDP and real exports. Our results are consistent with previous findings of Hye and Riaz (2008); Ahmad et al. (2012); Masuduzzaman (2012); Shahbaz and Feridun (2012); Javid et al. (2013); Atif and Siddiqi (2010); Ahmad et al. (2012); Noor and Siddiqi (2010); Uslu and Polat (2011). The exchange rate is declared to be significant at the 1 percent level of significance in real GDP. Appreciation of exchange rate will increase the prices of imported machinery and technology. It will discourage the domestic investors to invest in the country to increase the production. Fall in investment will cause a reduction in productivity, real GDP and real Exports. Based on an empirical analysis positive association is found between Exchange Rate, real GDP and real Exports.

Table 5

\begin{tabular}{|c|c|c|c|c|}
\hline Variables & Coefficients & Standard Errors & T-Statistics & Conclusion \\
\hline \multicolumn{5}{|c|}{ Dependent Variable: REAL GDP } \\
\hline LLABF & 1.840 & 0.850 & 2.160 & Significant \\
\hline LCAP & 1.820 & 0.710 & 2.560 & Significant \\
\hline LELPR & 0.680 & 0.220 & 3.090 & Significant \\
\hline LEXR & -1.530 & 0.640 & -2.390 & Significant \\
\hline LTOT & 1.950 & 0.870 & 2.240 & Significant \\
\hline \multicolumn{5}{|c|}{ Dependent Variable: REAL EXPORTS } \\
\hline LLABF & 4.320 & 1.410 & 3.060 & Significant \\
\hline LCAP & 0.370 & 0.300 & 1.230 & Insignificant \\
\hline LELPR & 1.910 & 0.390 & 4.860 & Significant \\
\hline LEXR & -2.630 & 0.380 & -6.860 & Significant \\
\hline LRPR & 1.020 & 0.330 & 3.040 & Significant \\
\hline LRGDP & 2.560 & 1.240 & 2.050 & Significant \\
\hline
\end{tabular}

Terms of Trade are found to be significant at the 1 percent level of significance with real GDP. It has a coefficient value of 1.95. It means that a one percent increase in the terms of trade will cause a 1.95 percent increase in the real GDP on the average. It may be justified as a rise in export prices boost up profit of domestic producers. They will produce more in order to make higher profits. In the sense, real GDP will rise. As regards to Relative Prices, it was expected to be positively correlated with real exports. Cheaper domestic goods and services will have a positive effect on supply locally as well as internationally. In the results, it is having positive coefficient value with significant t-value. Real GDP is appearing to have significant influence on Real Exports of Pakistan during the period of study with coefficient 2.56. Higher GDP motivates foreigners to trade with the nation by 
producing a higher level of output with more efficient resources at cheaper cost. In the study, results show similar estimates as according to the theory.

\section{Vector Error Correction (Short Run Results)}

Short run results based on Vector Error Correction Model (VECM) are reported in table 6 . The speed of adjustment term is the most important in the short run. It shows that how much time would be taken by the economy to reach at long run equilibrium from the short run equilibrium. The economy will converge towards long run equilibrium when a negative sign with a speed of adjustment term and positive sign shows that economy diverges from the long run equilibrium. Here these models show that the economy converges towards the long run equilibrium due to the negative sign of the coefficient in both models.

Table 6

Short Run Results

\begin{tabular}{|c|c|c|}
\hline VARIABLES & $\begin{array}{c}\text { Model } 1 \\
\text { D(LRGDP) }\end{array}$ & $\begin{array}{c}\text { Model 2 } \\
\text { D(LEXPORTS) } \\
\end{array}$ \\
\hline \multirow[t]{3}{*}{ Error Correction Term } & -0.03307 & -0.152928 \\
\hline & $(0.01109)$ & $(0.05479)$ \\
\hline & {$[-2.98196]$} & {$[-2.79136]$} \\
\hline D(LREXPT $(-1))$ & & $\begin{array}{r}-0.182966 \\
(0.15719) \\
{[-1.16395]}\end{array}$ \\
\hline \multirow[t]{3}{*}{ D(LRGDP (-1)) } & 0.101551 & -0.886881 \\
\hline & $(0.18431)$ & $(1.13031)$ \\
\hline & [ 0.55098$]$ & {$[-0.78464]$} \\
\hline \multirow{3}{*}{ D(LLABF (-1)) } & 0.115713 & 1.545386 \\
\hline & $(0.14352)$ & $(0.79863)$ \\
\hline & {$[0.80622]$} & [ 1.93505$]$ \\
\hline \multirow{3}{*}{$\mathrm{D}(\operatorname{LCAP}(-1))$} & -0.020034 & 0.199799 \\
\hline & $(0.03515)$ & $(0.23839)$ \\
\hline & {$[-0.56992]$} & {$[0.83813]$} \\
\hline \multirow[t]{3}{*}{ D(LELPR $(-1))$} & 0.151389 & 0.087221 \\
\hline & $(0.07882)$ & $(0.47125)$ \\
\hline & [ 1.92063$]$ & [ 0.18508$]$ \\
\hline \multirow{3}{*}{ D(LEXR(-1)) } & -0.109611 & 0.001048 \\
\hline & $(0.05331)$ & $(0.31897)$ \\
\hline & {$[-2.05614]$} & [ 0.00329$]$ \\
\hline \multirow[t]{3}{*}{$\mathrm{D}(\operatorname{LTOT}(-1))$} & 0.006771 & \\
\hline & $(0.03709)$ & \\
\hline & {$[0.18257]$} & \\
\hline \multirow[t]{3}{*}{ D(LRPR $(-1))$} & & 0.160672 \\
\hline & & $(0.13907)$ \\
\hline & & [ 1.15537$]$ \\
\hline \multirow{3}{*}{ Constant } & 0.036586 & 0.006426 \\
\hline & $(0.00984)$ & $(0.05837)$ \\
\hline & [3.71733] & {$[0.11010]$} \\
\hline R-squared & 0.566900 & 0.622744 \\
\hline Adj. R-squared & 0.532606 & 0.553430 \\
\hline F-statistic & 4.732067 & 5.906184 \\
\hline
\end{tabular}

Source: Authors Estimation 


\section{Concluding Remarks}

The aim of the study is to examine the influence of Electricity Generation on the Real GDP and real Exports of Pakistan using Solow Growth model. For this purpose, the study uses annual time series data ranging from 1972 to 2014. To estimate the results, the study employs the Log-Log forms of models in the Johansen Cointegration test. The Augmented Dickey Fuller test concludes that all variables are stationary at 1st difference.

The long run results reveal that Electricity Generation, Employed Labour Force, Gross Fixed Capital Formation and Terms of Trade have a positive association with Real GDP while Exchange Rate has a negative effect on Real GDP. In exports model, Electricity Generation, Employed Labour Force, Gross Fixed Capital Formation, Relative Inflation and Real GDP are found to be positive with Real Exports while Exchange Rate has a negative association with real Exports.

On the basis of our results we may suggest that in order to increase the real GDP and real Exports, the Government must increase the production of the electricity by constructing new dams and Thar Coal Power Project immediately. The government should make sincere efforts to maintain Terms of Trade so that it may be useful for exports. The private sector should be encouraged to invest rather than Privatization so that labour force may get the employment opportunities with all future benefits. The exchange rate may be controlled by fixed policy, but it is not desirable as long run policy making if managed by flexible exchange rate policy it would be more beneficial for the economy. 


\section{References}

Ahmad, N., Hayat, M. F., Hamad, N., \& Luqman, M. (2012). Energy consumption and economic growth: Evidence from Pakistan. Australian Journal of Business and Management Research, 2(6), 9-14.

Aktaş, C., \& Yilmaz, V. (2012). Causal relationship between electricity consumption and economic growth in Turkey. Uluslararası Yönetim İktisat ve İsletme Dergisi, 4(8), $45-54$.

Alam, M. S., Raza, S. A., Shahbaz, M., \& Abbas, Q. (2015). Accounting for contribution of trade openness and foreign direct investment in life expectancy: The long-run and short-run analysis in Pakistan. Social Indicators Research, 1-16. doi: 10.1007/ s11205-015-1154-8

Aqeel, A., \& Butt, M. S. (2001). The relationship between energy consumption and economic growth in Pakistan. Asia-Pacific Development Journal, 8(2), 101-110.

Asafu-Adjaye, J. (2000). The relationship between energy consumption, energy prices and economic growth: time series evidence from Asian developing countries. Energy economics, 22(6), 615-625.

Atif, S. M., \& Siddiqi, M. W. (2010). The electricity consumption and economic growth nexus in Pakistan: A new evidence. Retrieved from http://www.econstor.eu/ bitstream/10419/65688/1/AtifSM_EconomicGrowthAndElectricityConsumption -TodaYamamoto.pdf

Chontanawat, J., Hunt, L. C., \& Pierse, R. (2006). Causality between energy consumption and GDP: evidence from 30 OECD and 78 non-OECD countries. Retrieved from http://www.seec.surrey.ac.uk/Research/SEEDS/SEEDS113.pdf

Dhungel, K. R. (2008). A causal relationship between energy consumption and economic growth in Nepal. Asia Pacific Development Journal, 15(1), 137-150.

Hye, Q. M. A., \& Riaz, S. (2008). Causality between energy consumption and economic growth: the case of Pakistan. The Lahore Journal of Economics, 13(2), 45-58.

Javid, A. Y., Javid, M., \& Awan, A. Z. (2013). Electricity consumption and economic growth: Evidence from Pakistan. Economics and Business Letters, 2(1), 21-32.

Jawaid, S. T. (2014). Trade Openness and Economic Growth A Lesson from Pakistan. Foreign Trade Review, 49(2), 193-212.

Jawaid, S. T., \& Raza, S. A. (2012). Workers' remittances and economic growth in China and Korea: an empirical analysis. Journal of Chinese Economic and Foreign Trade Studies, 5(3), 185-193.

Johansen, S. (1988). Statistical analysis of cointegration vectors. Journal of economic dynamics and control, 12(2), 231-254.

Lackó, M. (1999). Do Power Consumption Data Tell the Story?-Electricity Intensity and Hidden Economy in Post-Socialist Countries (Tech. Rep.). Budapest Working Papers on the Labour Market.

Masuduzzaman, M. (2012). Electricity consumption and economic growth in Bangladesh: co-integration and causality analysis. Global Journal of Management and Business Research, 12(11), 47-56. 
Noor, S., \& Siddiqi, M. (2010). Energy consumption and economic growth in south asian countries: a co-integrated panel analysis. International Journal of Social, Behavioral, Educational, Economic, Business and Industrial Engineering, 4(7), 1731-1736.

Raza, S. A. (2015). Foreign direct investment, workers' remittances and private saving in Pakistan: an ARDL bound testing approach. Journal of Business Economics and Management, 16(6), 1216-1234.

Raza, S. A., Shahbaz, M., \& Nguyen, D. K. (2015). Energy conservation policies, growth and trade performance: Evidence of feedback hypothesis in Pakistan. Energy Policy, $80,1-10$.

Raza, S. A., Shahbaz, M., \& Paramati, S. R. (2016). Dynamics of Military Expenditure and income Inequality in Pakistan. Social Indicators Research, 1-21. doi: 10.1007/ s11205-016-1284-7

Shahbaz, M., \& Feridun, M. (2012). Electricity consumption and economic growth empirical evidence from Pakistan. Quality \& Quantity, 46(5), 1583-1599.

Uslu, E. E., \& Polat, Ö. (2011). Electricity Consumption, Employment and Real Income in Turkey. Enerji, Piyasa ve Duzenleme, 2, 1-20. Retrieved from http://epddergi .org/articles/2011/Uslu-Polat.pdf 